\title{
PENGARUH WAKTU FERMENTASI TERHADAP KADAR PROTEIN TEMPE BIJI DURIAN (Durio zibethinus) SEBAGAI SUMBER BELAJAR BIOLOGI SMA KELAS XII PADA MATERI BIOTEKNOLOGI PANGAN
}

\author{
Angges Sawitri ${ }^{1}$ \\ Handoko Santoso ${ }^{2}$ \\ ${ }^{1,2}$ Pendidikan Biologi FKIP Universitas Muhammadiyah Metro \\ E-mail: anggessafitri@y mail.com
}

\begin{abstract}
Tempeh is one of the original Indonesian fermented foods that have been recognized by the world. Tempeh is made by fermentation using the fungus Rhizopus Sp. Raw materials used in this research that waste durian seeds (Durio zibethinus). The purpose of this study were 1) To determine the effect of fermentation time on the levels of protein produced. 2) To determine the best fermentation time resulted in the highest protein content in soybean seeds of durian.

Place tempeh manufacturing is done in the Village of East Lampung Banjarrejo 38 $B$, a protein analysis carried out in the Laboratory Polytechnic Bandar Lampung on November $23^{\text {th }} 2013$, whereas organoleptic tests carried out in the Laboratory of Integrated Science Education, University of Muhammadiyah Metro. Research design used was completely randomized design with 4 treatments and 5 replications of the entire population of tempeh durians and parameter measured is the rate of crude protein and tempeh organoleptick durians.
\end{abstract}

The method used to measure the protein content of soybean seeds durian is the Gunning method and organoleptic test durian seed tempeh which include color, odor, texture, taste, and acceptance of soybean seed durian. The number of panelists used is 25 people.Data results obtained protein levels were tested by analysis of variance followed by testing Honestly Significant Difference (HSD) significance level of 5\% and 1\%. Research data shows that there is a very significant influence on the fermentation time the protein content soybean seeds of durian (Durio zibethinus).

The results showed a second treatment with fermentation time of 48 hours has the highest protein content of $3,3748 \%$. The benefits of making tempeh durian seed research are: the lecturer can be used as a learning resource in the study of the biology of food biotechnology, the community can be used as a guide in making tempeh and nutritional content to know the community, and can be used as ingredients in research-related information.

Kata Kunci: kadar protein, waktu fermentasi, tempe biji durian

Pengolahan buah-buahan merupakan salah satu cara dapat diolah menjadi sumber makanan baru salah satunya biji buah durian (Durio zibethinus). Buah durian mempunyai nilai ekonomis yang cukup baik di antara jenis buah lainnya. Buah durian hanya dikonsumsi daging buahnya sedangkan bijinya belum banyak dimanfaatkan. Biji durian yang dibuang sebagai limbah berupa sampah dapat mengganggu kualitas dan kesehatan lingkungan. Biji durian memiliki banyak kandungan seperti air, protein, lemak, karbohidrat, serat kasar dan abu. Sehingga dapat diolah menjadi produk pangan. Sejauh ini biji durian dimanfaatkan sebagai makanan 
ringan dengan cara direbus untuk dibuat makanan ringan sejenis kripik, dibuat tepung sebagai bahan substitusi pada jenang atau dodol, serta bahan baku pembuat kecap dan gula cair. Dalam hal ini penting untuk diketahui dalam pengolahan biji durian harus dipanaskan atau direbus dengan suhu $80^{\circ} \mathrm{C}$ untuk menghilangkan racun asam sikloropena yang terdapat di dalam biji durian (Djaeni, 2010). Olahan yang barasal dari biji durian ini belum banyak beredar di pasaran dan belum banyak diminati oleh masyarakat. Hal ini memotivasi peneliti untuk memanfaatkan biji durian sebagai terobosan baru dengan mengeluarkan produk baru yaitu tempe.

Pemanfaatan limbah biji durian sebagai bahan pembuatan tempe diharapkan akan memberikan pengaruh positif bagi masyarakat untuk dapat memanfaatkan biji durian. Sehubungan dengan pengolahan pangan, lingkungan sekitar akan menjadi sumber belajar dan inspirasi bagi siswa untuk mengembangkan kreativitas pengolahan pangan. Kreativitas dapat diwujudkan melalui tempe. Di sekolah-sekolah topik Bioteknologi Pangan biasanya hanya sebatas pemberian materi saja oleh guru. Dalam praktikum maka umumnya berupa pembuatan tempe dari kedelai saja. Padahal tempe dapat dibuat dengan berbagai bahan baku lainnya seperti biji turi, biji kecipir, biji kara benguk, biji lamtoro, ampas tahu, ampas kacang tanah, ampas kelapa dan beberapa jenis biji-bijian lain dapat diolah menjadi tempe. Sangat jarang sekali guru yang mengadakan praktikum dengan topik pembuatan tempe dengan bahan dasar lain, seperti biji durian.
Untuk meningkatkan kadar protein pada biji durian maka dilakukan cara pengolahan biji durian tersebut secara fermentasi yaitu menjadikannya produk tempe. Dengan fermentasi makanan akan memiliki nilai gizi yang lebih tinggi dibandingkan bahan asalnya karena komponen kompleks yaitu protein diubah oleh mikroorganisme menjadi asam amino. Mikroorganisme yang berperan memecahkan protein menjadi asam-asam amino yaitu Rhizopus oligosporus (Silvia, 2009).

Berdasarkan uraian di atas, peneliti tertarik untuk memanfaatkan biji durian sebagai bahan untuk membuat tempe dengan menvariasikan waktu fermentasi dan menganalisis kadar protein pada setiap variasi waktu fermentasi. Dengan permasalahan dalam penelitian ini adalah: 1) apakah waktu fermentasi berpengaruh trhadap kadar protein tempe biji durian yang dihasilkan? 2) Berapa lama waktu fermentasi yang menghasilkan kadar protein tertinggi pada tempe biji durian?

Hasil penelitian ini diharapkan mampu memberi manfaat: 1)Bagi masyarakat dapat digunakan sebagai petunjuk dalam membuat tempe dari biji durian dan kandungan gizinya dapat diketahui masyarakat luas. 2) Bagi pengajar khususnya guru dapat digunakan sebagai sumber belajar biologi dalam kajian Bioteknologi Pangan. 3) Dapat dijadikan bahan informasi dalam penelitian yang berkaitan.

\section{METODE}

Penelitian menggunakan metode eksperimen dengan Rancangan Acak Lengkap (RAL) dengan waktu yang digunakan yaitu 36, 48 jam, 60 jam, dan 72 jam sebagai perlakuan dengan 
setiap perlakuan menggunakan ulangan 5 kali.

\section{Cara kerja pembuatan tempe} diadaptasi dari Silvia, 2009:

a. Mencuci biji durian dengan air bersih

b. Menuangkan biji durian ke dalam panci dan diberi air secukupnya.

c. Merebus isi biji durian selama kurang lebih 30 menit.

d. Setelah merebus kurang lebih 30 menit, kemudian meniriskan lalu merendam biji durian dalam air yang pHnya 4-5 selama 24 jam.

e. Setelah merendam, mengupas bagian kulit luarnya.

f. Memotong biji durian kecil-kecil dengan ukuran $0,5 \times 0,5 \mathrm{~cm}$ sebanyak $1500 \mathrm{~g}$.

g. Mencuci biji durian sampai bersih

h. Merebus kembali biji durian kurang lebih selama 30 menit.

i. Meniriskan biji durian hingga benar-benar kering.

j. Menimbang ragi tempe sebanyak 2 gram dan $150 \mathrm{~g}$ biji durian.

k. Menaburkan ragi pada biji durian lalu mengaduk sampai rata.

1. Menyiapkan plastik dengan ukuran $10 \times 10 \mathrm{~cm}$ yang sudah dilubangi bagian sisinya dengan menggunakan jarum yang berukuran besar untuk setiap sisi atas dan sisi bawah.

m. Memasukkan biji durian ke dalam plastik.

n. Menutup plastik dengan rapat bisa dilakukan dengan api lilin.

o. Menyimpan tempe di dalam lemari dan diberi alas yang memungkinkan adanya sirkulasi udara pada bagian bawah bungkusan tempe.

p. Memfermentasikan selama 36 jam sebagai perlakuan pertama, 48 jam sebagai perlakuan kedua, 60 jam sebagai perlakuan ketiga dan 72 jam sebagai perlakuan keempat dengan masing-masing ulangan sebanyak lima kali.

q. Tempat yang akan digunakan untuk membuat tempe terlebih dahulu dipantau suhu sekitar 300C dan kelembapan 70-80\% yang sesuai untuk pertumbuhan kapang tempe.

\section{Penentuan kadar protein (Metoda Gunning)}

a. Menimbang $0,5-1,0$ gr bahan yang telah dihaluskan dan memasukkan kedalam labu Kjeldahl, menambahkan $10 \mathrm{gr}$ $\mathrm{K}_{2} \mathrm{~S}$ atau $\mathrm{Na}_{2} \mathrm{SO}_{4}$ anhidrat, dan 10-15 $\mathrm{ml} \mathrm{H}_{2} \mathrm{SO}_{4}$ pekat. Kalau distruksi sukar dilakukan perlu ditambah 0,1-0,3 gr $\mathrm{CuSO}_{4}$ dan dikocok.

b. Kemudian melakukan distruksi diatas pemanas listrik dalam lemari asam. Mula-mula dengan api kecil, setelah asap hilang api dibesarkan, pemanasan diakhiri setelah cairan menjadi jernih sedikit kebiruan.

c. Membuat perlakuan blanko, yaitu perlakuan di atas tanpa sampel.

d. Setelah dingin, menambahkan 100 $\mathrm{ml}$ aquades kedalam labu kjeldhal, serta larutan $\mathrm{NaOH} 45 \%$ sampai cairan basis. Memasang labu Kjeldahl dengan segera pada alat Distilasi.

e. Memanaskan labu Kjeldahl sampai amonia menguap semua, menampung distilat dalam erlenmeyer berisi $25 \mathrm{ml} \mathrm{HCl} 0,1$ $\mathrm{N}$ yang sudah diberi indikator fenolfptalein $1 \%$ beberapa tetes. Mengakhiri distilasi setelah distilat tertampung sebanyak 150 $\mathrm{ml}$ atau setelah distilat yang keluar tidak berbasis.

f. Kelebihan $\mathrm{HCl} \quad 0,1 \mathrm{~N}$ dalam distilat dititrasi dengan larutan $\mathrm{NaOH} 0,1 \mathrm{~N}$ hingga warna merah 
muda, catat jumlah $\mathrm{NaOH}$ yang digunakan.

$\% \mathrm{~N}=\frac{\text { (ml NaOH blanko }-\mathrm{ml} \mathrm{NaOH} \text { contoh }) \times \mathrm{N} \mathrm{NaOH} \times 14,008}{\text { gr. contoh } \times 10}$

$\%$ Protein $=\% \mathrm{~N} \times$ Faktor konversi

Penilaian Uji Organoleptik

Uji organoleptik adalah uji yang dilakukan dengan alat indra pengecap, uji dilakukan dilingkungan sekitar kampus Universitas Muhammadiyah Metro. Penilaian ini meliputi warna, rasa, bau, dan tekstur yang ditentukan dengan uji kesukaan panelis. Panelis yang digunakan berjumlah 25 orang panelis yang suka makan tempe, yang akan melakukan uji organoleptik terhadap sampel tempe biji durian. Pengambilan data dilakukan dengan memberikan angket kepada para panelis dengan rentang skor dari 1 sampai 3 . Semakin tinggi skor penilaian maka semakin baik kualitas tempe biji durian. Setelah data terkumpul, data ditabulasi dan di rata-rata hasilnya.

\section{HASIL}

Data hasil pengujian lama fermentasi biji durian terhadap kadar protein tempe biji durian dapat dilihat pada table 1 di bawah ini.

Tabel 1. Data Kadar Protein Tempe Biji Durian

\begin{tabular}{|c|c|c|c|c|c|c|c|}
\hline \multirow[t]{2}{*}{ No } & \multirow{2}{*}{$\begin{array}{l}\text { Kode } \\
\text { Sampel }\end{array}$} & \multirow{2}{*}{$\begin{array}{l}\text { Sampel } \\
\text { (gr x10) }\end{array}$} & \multicolumn{2}{|c|}{ Titrasi (ml) } & \multirow{2}{*}{$\begin{array}{l}\text { Protein } \\
(\%)\end{array}$} & \multirow{2}{*}{$\begin{array}{l}\text { Total } \\
(\%)\end{array}$} & \multirow{2}{*}{$\begin{array}{l}\text { Rata-rata } \\
(\%)\end{array}$} \\
\hline & & & Blanko & Sampel & & & \\
\hline 1 & 36.1 & 10,483 & 32,3 & 28,7 & 2,8813 & \multirow[t]{5}{*}{14,6738} & \multirow[t]{5}{*}{2,9348} \\
\hline 2 & 36.2 & 11,011 & 32,3 & 28,6 & 2,8752 & & \\
\hline 3 & 36.3 & 10,898 & 32,3 & 28,6 & 2,9724 & & \\
\hline 4 & 36.4 & 9,787 & 32,3 & 29,0 & 2,952 & & \\
\hline 5 & 36.5 & 9,653 & 32,3 & 29,0 & 2,9929 & & \\
\hline 6 & 48.1 & 12,940 & 32,3 & 27,4 & 3,3153 & \multirow[t]{5}{*}{16,8742} & \multirow[t]{5}{*}{3,3748} \\
\hline 7 & 48.2 & 10,851 & 32,3 & 27,9 & 3,3245 & & \\
\hline 8 & 48.3 & 10,245 & 32,3 & 28,7 & 3,4123 & & \\
\hline 9 & 48.4 & 10,182 & 32,3 & 28,3 & 3,4235 & & \\
\hline 10 & 48.5 & 10,226 & 32,3 & 28,2 & 3,3986 & & \\
\hline 11 & 60.1 & 11,037 & 32,3 & 29,1 & 2,5423 & \multirow[t]{5}{*}{12,7722} & \multirow[t]{5}{*}{2,5544} \\
\hline 12 & 60.2 & 11,844 & 32,3 & 28,5 & 2,5324 & & \\
\hline 13 & 60.3 & 10,355 & 32,3 & 29,4 & 2.5547 & & \\
\hline 14 & 60.4 & 10,334 & 32,3 & 29,2 & 2,5613 & & \\
\hline 15 & 60.5 & 10,467 & 32,3 & 29,5 & 2,5815 & & \\
\hline 16 & 72.1 & 10,393 & 32,3 & 29,4 & 2,4031 & \multirow[t]{5}{*}{12,2837} & \multirow[t]{5}{*}{2,4567} \\
\hline 17 & 72.2 & 11,590 & 32,3 & 29,1 & 2,4124 & & \\
\hline 18 & 72.3 & 10,688 & 32,3 & 29,3 & 2,4256 & & \\
\hline 19 & 72.4 & 10,462 & 32,3 & 29,4 & 2,5641 & & \\
\hline 20 & 72.5 & 10,473 & 32,3 & 29,4 & 2,4785 & & \\
\hline
\end{tabular}

Keterangan:

36 1, 36 2, 36 3, 36 4, 36 5: Lama fermentasi 36 jam 48 1, 48 2, 48 3, 48 4, 48 5: Lama fermentasi 48 jam 60 1, 60 2, 60 3, 60 4, 60 5: Lama fermentasi 60 jam 72 1, 72 2, 72 3, 72 4, 72 5: Lama fermentasi 72 jam 


\section{Data Hasil Uji Organoleptik}

a. Data Uji Organoleptik Warna Tempe Biji Durian

Tabel2. Data Uji Organoleptik Warna Tempe Biji Durian.

\begin{tabular}{l|c|c|c}
\hline \multirow{2}{*}{ Perlakuan } & \multicolumn{3}{|c}{ Skor } \\
\cline { 2 - 4 } & $\mathbf{1}$ & $\mathbf{2}$ & $\mathbf{3}$ \\
\hline A (Fermentasi 36 jam) & $8 \%$ & $52 \%$ & $40 \%$ \\
B (Fermentasi 48 jam) & $0 \%$ & $40 \%$ & $60 \%$ \\
C (Fermentasi 60 jam) & $4 \%$ & $56 \%$ & $40 \%$ \\
D (Fermentasi 72 Jam) & $4 \%$ & $64 \%$ & $28 \%$ \\
\hline
\end{tabular}

Ket. 1 (kuning), 2 (putih kekuningan), 3 (putih)

b. Data Uji Organoleptik Bau Tempe Biji Durian

Tabel 3. Data Uji Organoleptik Bau Tempe Biji Durian

\begin{tabular}{l|l|l|l}
\hline \multirow{2}{*}{ Perlakuan } & Skor & $\mathbf{2}$ \\
\cline { 2 - 4 } & $\mathbf{1}$ & $56 \%$ & $36 \%$ \\
\hline A (Fermentasi 36 jam) & $8 \%$ & $24 \%$ & $56 \%$ \\
B (Fermentasi 48 jam) & $20 \%$ & $44 \%$ & $48 \%$ \\
C (Fermentasi 60 jam) & $12 \%$ & $44 \%$ & $48 \%$ \\
D (Fermentasi 72 Jam) & $8 \%$ & . & \\
\hline
\end{tabular}

Ket: 1 (Tidak khas tempe), 2 (Kurang khas tempe), 3 (Khas tempe)

c. Data Uji Organoleptik Tekstur Tempe Biji Durian

Tabel4. Data Uji Organoleptik Tekstur Tempe Biji Durian

\begin{tabular}{l|c|c|c}
\hline \multirow{2}{*}{ Perlakuan } & \multicolumn{3}{|c}{ Skor } \\
\cline { 2 - 4 } & $\mathbf{1}$ & $\mathbf{2}$ & $\mathbf{3}$ \\
\hline A (Fermentasi 36 jam) & $12 \%$ & $64 \%$ & $24 \%$ \\
B (Fermentasi 48 jam) & $4 \%$ & $40 \%$ & $56 \%$ \\
C (Fermentasi 60 jam) & $4 \%$ & $52 \%$ & $44 \%$ \\
D (Fermentasi 72 Jam) & $16 \%$ & $40 \%$ & $44 \%$ \\
\hline
\end{tabular}

Ket: 1 (Tidak lunak), 2 (Kurang lunak), 3 (Lunak)

d. Data Uji Organoleptik Rasa Tempe Biji Durian

Tabel 5. Data Uji Organoleptik Rasa Tempe Biji Durian

\begin{tabular}{l|c|c|c}
\hline \multirow{2}{*}{ Perlakuan } & \multicolumn{3}{|c}{ Skor } \\
\cline { 2 - 4 } & $\mathbf{1}$ & $\mathbf{2}$ & $\mathbf{3}$ \\
\hline A (Fermentasi 36 jam) & $4 \%$ & $56 \%$ & $40 \%$ \\
B (Fermentasi 48 jam) & $4 \%$ & $32 \%$ & $64 \%$ \\
C (Fermentasi 60 jam) & $8 \%$ & $32 \%$ & $60 \%$ \\
D (Fermentasi 72 Jam) & $8 \%$ & $40 \%$ & $52 \%$ \\
\hline
\end{tabular}

Ket: 1 (Tidak Enak), 2 (Ku rang Enak), 3 (Enak)

e. Data Uji Organoleptik Daya Terima Tempe Biji Durian

Tabel6. Data Uji Organoleptik Daya Terima Tempe Biji Durian

\begin{tabular}{l|c|c|c}
\hline \multirow{2}{*}{ Perlakuan } & \multicolumn{3}{|c}{ Skor } \\
\cline { 2 - 4 } & $\mathbf{1}$ & $\mathbf{2}$ & $\mathbf{3}$ \\
\hline A (Fermentasi 36 jam) & $4 \%$ & $52 \%$ & $44 \%$ \\
B (Fermentasi 48 jam) & $0 \%$ & $40 \%$ & $60 \%$ \\
C (Fermentasi 60 jam) & $4 \%$ & $44 \%$ & $52 \%$ \\
D (Fermentasi 72 Jam) & $8 \%$ & $44 \%$ & $48 \%$ \\
\hline
\end{tabular}

Ket: 1 (Tidak Suka), 2 (Ku rang Suka), 3 (Suka) 
PEMBAHASAN

Kadar Protein Tempe Biji Durian

Karmini

(2007:1)

menyatakan: Fermentasi merupakan tahap terpenting pada tahap proses pembuatan tempe. Selama proses fermentasi terjadi perubahan kimia pada kedelai. Perubahan tersebut terjadi karena substrat kedelai (protein, lemak, karbohidrat, dan senyawa-senyawa lainnya) didekomposisi menjadi molekulmolekul yang lebih kecil oleh enzimenzim yang dihasilkan kapang.

Dari pendapat di atas dapat diketahui bahwa enzim-enzim yang di miliki oleh kapang dapat mengurai senyawa-senyawa yang kompleks menjadi sederhana. Kadar protein pada biji durian yang masih mentah yaitu $2,57 \%$, setelah diberi perlakuan lama fermentasi maka protein semakin menurun. Menurunnya kadar protein pada tempe biji durian karena proses terhidrolisisnya protein dalam biji durian tersebut semakin besar. Oleh karena itu, semakin lama fermentasi maka kadar protein semakin rendah. Namun pada lama waktu fermentasi tertentu protein yang dimiliki oleh tempe biji durian meningkat. Hal ini sesuai dengan literatur yang menyatakan bahwa "peningkatan jumlah massa mikroba akan menyebabkan meningkatnya kandungan protein pada tempe" (Nurhayani dalam Puspitasari, 2009). Pertumbuhan jamur pada fase optimal, keberadaan jamur itu menyebabkan kandungan protein pada tempe biji durian meningkat.

Rhizopus menghasilkan protease yang menguraikan protein biji durian selama fermentasi. Selama proses fermentasi pada tempe biji durian tersebut, enzim yang dihasilkan oleh kapang dapat menghidrolisis protein yang terkandung di dalamnya. Protein yang terhidrolisis akan berubah menjadi asam amino yang juga bermanfaat bagi tubuh karena protein di dalam tubuh akan diubah menjadi asam-asam amino.

\section{Uji Organoleptik Tempe Biji Durian}

\section{a. Warna Tempe Biji Durian}

Berdasarkan data hasil uji organoleptik warna tempe biji durian dengan skala hedonik menunjukkan bahwa organoleptik warna tempe biji durian dengan waktu fermentasi 48 jam memiliki skor tertinggi yaitu $60 \%$ panelis yang memilih warna putih. Sedangkan skor terendah yaitu $28 \%$ panelis yang memilih warna putih pada tempe biji durian perlakuan lama fermantasi 72 jam. Warna putih pada tempe disebabkan adanya miselium kapang yang tumbuh pada permukaan tempe biji durian, sehingga sebagian besar panelis memilih warna tempe biji durian dengan lama waktu fermentasi 48 jam. Nababan (2012:5) menyatakan: Daya tarik suatu jenis makanan dipengaruhi oleh warna sebagai salah satu komponen yang dapat dilihat dan dapat merupakan bagian yang tidak terpisahkan dalam menjaga mutu. Warna makanan yang menarik dan tampak alamiah dapat meningkatkan cita rasa".

\section{b. Bau Tempe Biji Durian}

Uji organoleptik bau dari tempe biji durian dengan skala hedonik menunjukkan bahwa tempe biji durian dengan waktu fermentasi 48 jam memiliki skor tertinggi dimana $56 \%$ panelis memilih bau khas tempe. Bau khas pada tempe disebabkan terjadinya degradasi komponen-koponen dalam tempe biji durian selama berlangsungnya fermentasi. Menurut Rianne dalam Nababan (2012:5) "siklus aroma dan 
keinginan untuk mengkonsumsi makanan, tidak terjadi pada saat kita mengunyah makanan. Aroma yang dikeluarkan oleh makanan akan masuk ke hidung melalui lubang yang ada di dalam mulut".

\section{c. Tekstur Tempe Biji Durian}

Untuk uji organoleptik tekstur pada tempe biji durian. Hasil dari uji organoleptik untuk tekstur tempe biji durian yang menunjukkan hasil terbaik yaitu perlakuan B dengan waktu fermentasi 48 jam dimana $56 \%$ panelis menyatakan tempe biji durian bertekstur dengan kriteria lunak. Skor terendah yang menyatakan tempe biji durian bertekstur lunak yaitu terdapat pada waktu fermentasi 36 jam, dimana hanya $24 \%$ panelis yang menyatakan tempe biji durian bertekstur lunak. Menurut Purba (2013:24) "tekstur tempe akan menjadi lunak atau lembut karena terjadi penurunan selulosa menjadi bentuk yang sederhana". Selain itu proses perebusan juga mempengaruhi keadaan tekstur. Selama proses perebusan, maka kadar air yang ada pada biji durian akan meningkat, sehingga akan mempengaruhi tekstur tempe biji durian yang dihasilkan.

\section{d. Rasa Tempe Biji Durian}

Uji organoleptik untuk kriteria rasa dilakukan pada tempe biji durian yang sudah digoreng tapi tidak diberi bumbu. Adapun hasil uji organoleptik untuk rasa yang menunjukkan hasil terbaik adalah pada perlakuan B yaitu waktu fermentasi 48 jam dengan jumlah panelis yang menyatakan enak yaitu 64\% panelis. Skor terendah yang menyatakan tempe biji durian memilki rasa enak yaitu terdapat pada waktu fermentasi 36 jam, dimana hanya $40 \%$ panelis yang menyatakan tempe biji durian memiliki rasa enak. Fermentasi biji durian menjadi tempe mampu mengubah aroma langu menjadi aroma yang khas pada tempe, begitu juga dengan rasa, yang khas pada tempe biji durian (Astwan dalam Purba, 2013:24).

\section{e. Daya Terima Tempe Biji Durian}

Berdasarkan data hasil uji organoleptik daya terima tempe biji durian, perlakuan yang menunjukkan tempe biji durian yang memiliki skor tertinggi yaitu tempe biji durian pada perlakuan B dengan waktu fermentasi 48 jam dimana $60 \%$ panelis menyukai tempe biji durian. Skor terendah yang menyatakan tempe biji durian memilki rasa enak yaitu terdapat pada waktu fermentasi 36 jam, dimana hanya $40 \%$ panelis yang menyatakan tempe biji durian memiliki rasa enak. Daya terima adalah penilaian tentang suka atau tidak suka terhadap tempe biji durian meliputi warna, aroma, rasa, dan tekstur (Setyowati dkk, 2008:56). Menurut para panelis yang melakukan uji organoleptik pada tempe biji durian, kurang sukanya pada tempe biji durian karena saat pengujian berlangsung tempe biji durian yang digoreng kurang kering. Selain itu, kurang sukanya panelis terhadap tempe biji durian yaitu karena adanya sedikit lendir di dalam tempe biji durian.

Setelah direkomendasikan dari keempat perlakuan, menurut uji organoleptik yang dapat dikembangkan di kalangan masyarakat yaitu pembuatan tempe biji durian dengan perlakuan 48 jam. Pengujian organoleptik dengan panelis mahasiswa Universitas Muhammadiyah bertujuan untuk membuka wawasan bahwa suatu pangan yang tidak bermanfaat dapat dimanfaatkan dengan cara 
mengolahnya menjadi suatu makanan.

Manfaat Hasil Penelitian Sebagai Sumber Belajar Biologi dalam Proses Pembelajaran

Dari penelitian tersebut diperoleh hasil bahwa waktu fermentasi mempengaruhi kadar protein pada tiap perlakuan waktu. Berdasarkan fakta yang diperoleh dari hasil penelitian, maka dapat digeneralisasikan dalam bentuk konsep yaitu: a) Hasil penelitian dapat digunakan dalam rancangan atau model sumber belajar siswa SMA kelas IX semester genap, pada Standar Kompetensi memahami prinsip-prinsip dasar bioteknologi serta implikasinya pada salingtemas. b) Pemanfaatan hasil penelitian dalam pembelajaran berupa rancangan atau model sumber belajar dalam bentuk Lembar Kerja Praktikum Siswa (LKPS). c) Hasil penelitian menunjukkan bahwa waktu fermentasi mempengaruhi kadar protein tempe biji durian. d) Hasil penelitian ini juga dapat menambah pengetahuan bahwa masih banyak bahan-bahan yang dianggap tidak bernilai yang dapat dijadikan bahan penunjang atau pengganti yang bernilai.

Penelitian ini dapat dibahas pada topik Bioteknologi Pangan dengan indikator pencapaian hasil belajar siswa adalah membedakan bioteknologi tradisional dan modern, membuat produk bioteknologi tradisional. Sehingga guru dapat menggunakan kekayaan alam sebagai lingkungan sumber belajar seperti biji durian. Penelitian ini memanfaatkan biji durian yang banyak terdapat di lingkungan sekitar dengan menggunakan peranan mikroorganisme (jamur Rhizopus oligosporus) pada pembuatan tempe biji durian sehingga dapat dijadikan sebagai sumber belajar biologi SMA kelas XII semester genap pada topik bahasan Bioteknologi Pangan.

Selain itu penelitian ini memanfaatkan limbah biji durian yang biasanya belum dimanfaatkan dan hanya terbuang begitu saja. Limbah biji durian ternyata memiliki potensi untuk dapat diolah lebih lanjut menjadi tempe sehingga lebih bernilai ekonomi. Hakikatnya dalam proses pembelajaran Biologi tidak hanya terfokus pada materi yang terdapat dalam buku namun dapat langsung dikaitkan dengan alam sekitar, dan siswa dapat langsung mengamati fakta yang ada pada lingkungan sekitar

Melalui pengamatan langsung di alam sekitar harapannya siswa dapat dengan mudah memahami materi biologi. Dalam proses pembelajaran ini guru menggunakan strategi pembelajaran yang mengacu pada diskusi, ceramah, dan eksperimen. Alokasi waktu yang digunakan tiga kali pertemuan. Sebagai sumber belajar penelitian tempe biji durian ini dapat disajikan dalam bentuk LKPS (Lembar Kerja Praktikum Siswa). Di dalam LKPS yang diterapkan di sekolah yaitu memuat proses pembuatan tempe biji durian. Sedangkan untuk uji kadar protein kasar, dapat dilakukan jika laboratorium PMIPA sekolah memiliki alat dan bahan yang mendukung. Keterbatasannya laboratorium bisa dirubah dengan menggunakan uji organoleptik.

\section{KESIMPULAN}

Ada pengaruh lama fermentasi tempe biji durian terhadap kadar protein tempe biji durian. Hasil penelitian menunjukkan bahwa pada tiap perlakuan dengan lama waktu 
fermentasi yang berbeda menunjukkan adanya perbedaan kadar protein yang dihasilkan. Perlakuan lama fermentasi 48 jam menghasilkan kadar protein paling tinggi dengan rata-rata $3,3748 \%$. Dari keempat perlakuan yang direkomendasikan untuk dikembangkan di masyarakat menurut uji organoleptik adalah pembuatan tempe biji durian dengan perlakuan 48 jam. Hasil penelitian ini digunakan sebagai rancangan atau model sumber belajar Biologi SMA kelas XII semester genap berupa Lembar Kerja Praktikum Siswa (LKPS) pada pokok bahasan Bioteknologi Pangan.

\section{SARAN}

Bagi peneliti, perlu dilakukan penelitan lebih lanjut mengenai biji durian ini khususnya cara menghilangkan lendir yang terdapat dalam biji durian. Perlakuan yang disarankan adalah perebusan dengan suhu yang tidak terlalu tinggi (tidak lebih dari $80^{\circ} \mathrm{C}$ ), perendaman selama 24 jam, dan fermentasi tempe biji durian yang tidak terlalu lama yaitu dengan menggunakan interval waktu 38 jam, 48 jam, 58 jam, dan 68 jam. Bagi guru sebagai rancangan atau model sumber belajar Biologi SMA kelas XII semester genap pada materi bahasan Bioteknologi Pangan melalui Lembar Kerja Praktikum Siswa, dalam kegiatan praktikum atau sebagai bahan diskusi siswa. Bagi masyarakat, biji durian ini bisa dijadikan diversifikasi pangan yaitu: pembuatan tempe biji durian.

\section{DAFTAR RUJUKAN}

Djaeni, Moh. 2010. Kelayakan Biji Durian Sebagai Bahan Pangan Alternatif: Aspek Nutrisi dan Tekno Ekonomi. Jurnal Riptek. (Online) Vol.4, No.II, Tahun
2010.

(http://eprints.undip.ac.id.

Diakses 17 Mei 2013).

Karmini, Mien dan Djoko Sutopo. 2007. Aktivitas Enzim Hidrolitik Kapang Rhizopus Sp Pada Proses Fermentasi Tempe. Jurnal litbang. (Http/lejournal.litbang.depkes. go.id. Diakses 25 Oktober 2013)

Nababan, Erika Fera; Ernawati Nasution; Fitri Ardiani. 2012. Uji Daya Terima Tempe Biji Kecipir Beras Merah dan Kandungan Gizinya. Journal: Gizi, Kesehatan Reproduksi dan Epidemiologi. (Online) Vol I, No 01, 2012. (http://jurnal.usu.ac.id.

Diakses 12 Maret 2013).

Purba, Lely Sefryinda; Sentosa Ginting; Mimi Nurminah. 2013. Perbandingan Berat Kacang Kedelai Bergerminasi dan Biji Nangka dan Konsentrasi Laru pada Pembuatan Tempe. Jurnal Rekayasa Pangan (Online) Vol.I.No.2 Th.2013. (http://eprints.undip.ac.id.

Diakses 12 November 2013)

Puspitasari, Ninis. 2009. Pengaruh Jenis Vitamin B dan Sumber Nitrogen Dalam Peningkatan Kandungan Protein Kulit Ubi Kayu Melalui Proses Fermentasi. Semarang: Universitas Diponegoro.

Setyowati, Rini; Dwi Sarbini; Sri Rejeki. 2008. Pengaruh Penambahan Bekatul Terhadap Kadar Serat Kasar, Sifat Organoleptik Dan Daya Terima Pada Pembuatan Tempe Kedelai (Glycine max (L) Meriil). Jurnal Penelitian Sains dan Teknologi. (Online) Vol 9, No.1,2008. 
(http://eprints.ums.ac.id. Di akses 12 Maret 2013).

Silvia, Ika. 2009. Pengaruh

Penambahan Variasi Berat

Inokulum Terhadap Kualitas

Tempe Biji Durian. Medan:

Universitas Sumatera Utara. 